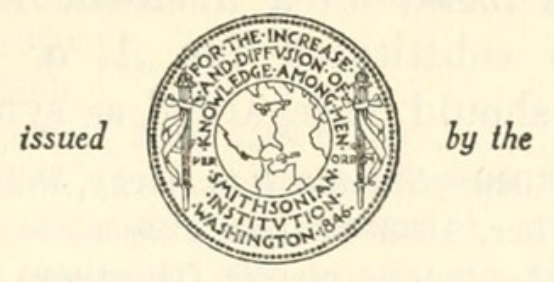

SMITHSONIAN INSTITUTION

U. S. NATIONAL MUSEUM

\title{
REPORT ON THE SMITHSONIAN-FIRESTONE EXPEDI- TION'S COLLECTION OF REPTILES AND AMPHIBIANS FROM LIBERIA
}

By Arthur Loveridge

Dr. William M. Mann, director of the National Zoological Park in Washington and leader of the Smithsonian-Firestone Expedition, 1940 , is to be congratulated on finding time to assemble a representative collection of the Liberian herpetofauna, despite the exacting duties involved in the capture and care of wild creatures, the securing of which was the primary purpose of his journey.

This collection, consisting as it does of over 500 specimens representing 56 species, naturally adds considerably to our knowledge of the lower vertebrates of the country whose fauna is so imperfectly known as that of the Liberian Republic. Among the results of a study of this material, therefore, the following species have had to be described as new:

Typhlops manni, new species from Harbel.

Hylambates cochranae, new species from Bendaja.

Leptopelis bequaerti, new species from Gbanga, Gibi, etc.

Rana albolabris parkeriana, new name for acutirostris Parker, preoccupied.

(This is the Angolan race of the typical form occurring in Liberia.)

In addition we are able to add the undermentioned to the steadily growing list of species to be found within the boundaries of the Republic:

Boaedon lineatus lineatus.

Crotaphopeltis duchesnii guineensis.

Hylambates leonardi.
Rana longirostris.

Phrynobatrachus natalensis. 
Neusterophis variegatus should be substituted for Natrix fuliginoides, whose admission was based on a misidentification, and Agama $a$. africana (Hallowell) substituted for A. a. savatieri Rochebrune. Certain other species should be regarded as synonyms, viz:

Aliurus Dunn and Dunn, 1940=Hemidactylus Gray, 1827 (not 1825).

Tropidonotus ferox Günther, 1863=Natrix anoscopus anoscopus (Cope) 1861.

L. liberiensis Ahl, 1929=Leptopelis viridis (Günther) 1868.

while

Lacerta langi Schmidt is revived as a race of $L$. echinata Cope.

Helicops gendrii Boulenger as a race of Natrix anoscopus Cope.

Neusterophis variegatus (Peters) from synonymy of fuliginoides Günther.

Boaedon virgatus (Hallowell) is made a race of lineatus Duméril and Bibron.

Rana alleni (Barbour and Loveridge) a race of crassipes Peters.

Phrynobatrachus brongersmai Parker a race of ogoensis Boulenger.

Pertinent data regarding the material are supplied to enable fellow herpetologists in checking identifications or extending the known range of variation. I take this opportunity of thanking Dr. Doris M. Cochran and Dr. W. M. Mann for the privilege of studying this material now in the United States National Museum at Washington.

As none of the villages mentioned in this paper are to be found in Stieler's Atlas, the accompanying sketch map-kindly supplied by Dr. Leonard P. Schultz, of the National Museum-is intended to give the approximate positions of places from which specimens were obtained. Dr. Mann has kindly furnished me with the undermentioned information regarding them, together with dates of the itinerary. It has not been thought necessary to repeat these dates except where some notes concerning breeding are involved. As regards place names, Dr. Mann points out that no uniformity of spelling is to be found on maps or in his correspondence with government officials.

Bellyella: Spelling rendered in half a dozen different ways. No two maps of Liberia locate this village in the same place. Dr. Mann has placed it approximately in the position as given in the State Department's map. March 23-30, 1940.

Bendaja: Also spelled Bandeja, Bendeja, Bandaja, and Bendija. A village 5 or 6 miles from the border. May 14-27, 1940.

Bromley: A mission station on the St. Paul River above Monrovia. June 6-8, 1940.

Cape Mount: A name used locally for the Cape, the Mountain, the County, and the mission. Robertsport is the chief town and port for the Cape Mount district. May 7-12 and May 29-31, 1940.

Degain: Also spelled Dagain and Digain, a village where a night was spent on the journey to Bellyella and return. March 22 and 31, 1940.

Gibi: Also spelled Gebi. The name applied to a low range of mountains whose highest elevation is 2,042 feet. No collecting was carried out above 900 feet, however, for Dr. Mann's party stayed at Managey's town while in the vicinity. April 10-16, 1940. 
Harbel: This is the name of the Firestone Plantation, which covers an area of approximately 25 square miles. It was the expedition's headquarters from March 10 to July 17, 1940.

IMombo: May 13 and 28, 1940.

Reputa: Also spelled Wreputa. June 21-26, 1940.

Zorzor: A mission station on the frontier of French Guinea about two days' march, i. e., approximately 40 miles northwest of Bellyella. The locality was not visited by members of the expedition, and the only specimenstortoises-from this locality were sent in by the missionaries.

\section{TORTOISES}

\section{KINIXYS HOMEANA Bell}

1827. Kinixys Homeana BelL, Trans. Linn. Soc. London, vol. 15, p. 400, pl. 17, fig. 2 (West Africa).

4 ô $\hat{o}, 3$ 우 우 (U.S.N.M. Nos. 109685, 109689-90, 109692-3, 109698-9), Zorzor

A nuchal shield, except in U.S.N.M. No. 109698, which is also aberrant in possessing 21 marginals (all the rest have 22) and 5 (right) or 7 (left) costals (all the rest have 4 ); fifth vertebral descending abruptly in all.

Males, characterized by longer tail and concave plastron, have a gular suture, which is included in the total length of plastron $61 / 2^{-63 / 4}$ ( $7-71 / 2$ in females) times, and an abdominal suture $17 / 8-2$ (13/4 in females) times as long as the pectoral suture. Shell of largest $\hat{o}$ (U.S.N.M. No. 109689) measures 195 mm. over all; largest $q$ (U.S.N.M. No. 109685) measures $223 \mathrm{~mm}$.

KINIXYS EROSA (Schweigger)

1802. Testudo Denticulata SHaw (not of Linnaeus), General zoology, vol. 3, pt. 1, p. 59, pl. 13 ("Supposed to be a native of North America").

1814. Testudo erosa Schweigger, Prodromi monographiae Cheloniorum, p. 52 ("America septentrionali (Shaw)").

2 oิ ô, 6 우 (U.S.N.M. Nos. 109687-8, 109691, 109694-7), Zorzor

No nuchal shield; 22 marginals, except in U.S.N.M. No. 109696 which has 24 ; costals 4 ; fifth vertebral descending obliquely in all.

Males, characterized by longer tail and concave plastron, have a gular suture which is included in the total length of plastron $5 \frac{1}{2} 2^{-53 / 4}$ $\left(63 / 4^{-71} / 4\right.$ in females) times, and an abdominal suture $21 / 2^{-31 / 2}(2-3$ in females) times as long as the pectoral suture. Shell of largest $\hat{0}$ (U.S.N.M. No. 109688) measures $260 \mathrm{~mm}$. over all; largest $q$ (U.S.N.M. No. 109687) measures $242 \mathrm{~mm}$. 


\section{LIZARDS}

\section{HEMIDACTYLUS FASCIATUS Gray}

1842. Hemidactylus fasciatus GraY, Zool. Misc., 1842, p. 58 (no locality).

1845. Leiurus ornatus GRAY, Catalogue of the specimens of lizards in the collection of the British Museum, p. 157 (West Africa) (monotype, ornatus Gray; not Leiurus Hemprich and Ehrenberg, 1829, in Arachnida).

1856. Hemidactylus formosus Hallowell, Proc. Acad. Nat. Sci. Philadelphia, 1856, p. 148 (Liberia).

1862. Liurus ornatus Cope, in Slack, Handbook of the Museum of the Academy of Natural Sciences of Philadelphia, p. 32 (monotype, Hemidactylus ornatus Hallowell; not Liurus Ehrenberg, 1828, in Arachnida).

1940. Aliurus ornatus Dunn and Dunn, Copeia, 1940, p. 71 (substitute name for Liurus Cope, preoccupied by Liurus Ehrenberg, 1828, in Arachnida).

ô (U.S.N.M. No. 109631), Harbel

Midbody rows of dorsal tubercles 25; lamellae under first toe 8, under fourth toe 11; femoral pores $20+19$; subcaudals more than half the width of tail. Total length $182(85+97) \mathrm{mm}$.

The recently proposed generic name of Aliums Dunn and Dunn becomes a synonym of Hemidactylus, as will be seen from the somewhat complicated synonymy given above. I have been unable to examine Slack's rare Handbook and so quote the citation from it as given by Dunn and Dunn.

\section{AGAMA AGAMA AFRICANA (Hallowell)}

1844. Tropidolepis Africanus Hallowell, Proc. Acad. Nat. Sci. Philadelphia, 1844, p. 171 (Liberia).

1845. Calotes versicolor Hallowell (not of Daudin), Proc. Acad. Nat. Sci. Philadelphia, 1845, p. 247 (Liberia).

1884. Agama savatieri Rochebrune, Faune de la Sénégambie, Rept., p. 89, pl. 11, figs. 1, 2 (Bathurst, Gambia) (restricted).

\section{2 ô $\hat{o}, 2$ 우 우 (U.S.N.M. Nos. 109291-4), Bellyella}

우 (U.S.N.M. No. 109580), Bendaja

Midbody scale rows 60-64; preanal pores 12-14. Larger $\hat{o}$ measures $112 \mathrm{~mm}$. from snout to anus, tail truncate.

Heretofore (1936, p. 54) I have used savatieri for agamas of the extreme west, which have fewer midbody scale rows than typical $A$. a. agama of the Cameroons, but Hallowell's name africana, which was overlooked by Boulenger and all subsequent herpetologists, is undoubtedly an Agama and has a wide margin of priority over any other name that is applicable.

\section{LACERTA ECHINATA ECHINATA Cope}

1862. Lacerta (Zootoca) echinata Cope, Proc. Acad. Nat. Sci. Philadelphia, 1862, p. 189 (West Africa).

우 (U.S.N.M. No. 109632), Harbel 
Midbody scale rows 37 ; parietal present; gular granules between chin shields and collar 30 ; femoral pores $12+12$. Total length 342 $(97+245) \mathrm{mm}$.

Trinomials are used on account of L. e. langi Schmidt (1919) of the eastern Congo, which Boulenger (1920, p. 332) unjustifiably synonymized with echinata. The type of the latter (U.S.N.M. No. 5995) almost certainly came from Liberia, for it was described at the same time as Cophoscincus dura, whose type (U.S.N.M. No. 5996) was also said to be from West Africa yet is known only from Liberia.

\section{MABUYA BLANDINGII (Hallowell)}

1844. Euprepes Blandingii Hallowell, Proc. Acad. Nat. Sci. Philadelphia, 1844, p. 58 (Liberia).

1857. Euprepes frenatus Hallowell, Proc. Acad. Nat. Sci. Philadelphia, 1857, p. 50 (Liberia).
9 (U.S.N.M. Nos. 109024-32), Gibi
1 (U.S.N.M. No. 109295), Bromley
1 (U.S.N.M. No. 109581), Bendaja
1 (U.S.N.M. No. 109633), Harbel

Midbody scale rows 30-34; dorsals with 3 (in young) to 5, and rarely even 7 , keels; supranasals separated in five specimens, in contact in eight; prefrontals separated in four examples, in contact in nine; supraoculars 4 ; supraciliaries $3-6$. The largest, a 우 (U.S.N.M. No. 109295), measures only $182(74+108) \mathrm{mm}$. In its oviducts (April 10-16) are 4 eggs, measuring 12 by $7 \mathrm{~mm}$., but without embryos.

A good deal of variation is displayed in the matter of coloration. The dark brown lateral band is faintly edged above with white in a young skink, below by a sharply defined white band in four specimens, by a series of white flecks, or altogether lacking, in others. Below, pure white.

\section{COPHOSCINCOPUS DURUS (Cope)}

1862. Tiliqua dura Cope, Proc. Acad. Nat. Sci. Philadelphia, 1862, p. 190 (Western Africa).

1884. Cophoscincus simulans Vamlant, Bull. Soc. Philom. Paris, ser. 7, vol. 8, p. 170 (Couacrou, Ivory Coast).

1 (U.S.N.M. No. 109674), Gibi

The type of this interesting, though common, Liberian skink is in the National collection (U.S.N.M. No. 5996). In all probability it came from Liberia, as the only record of its occurrence elsewhere is that of Vaillant, whose type locality I have failed to trace, unless it be Kurako or Kurukoro, north of Ganta, in what is now French. Guinea. Owing to an unfortunate accident, the Gibi specimen is too dried to be of much taxonomic value. 


\section{CHAMAELEO GRACILIS GRACILIS Hallowell}

1842. Chamaeleo gracilis Hallowell, Journ. Acad. Nat. Sci. Philadelphia, vol. 8, p. 324 , pl. 18 (Liberia).

\section{2 ô $\hat{o}, 3$ 우 (U.S.N.M. Nos. 109019-23), Gibi}

Males with tarsal spurs. Larger ô measures $186(96+90) \mathrm{mm}$; largest + measures $280(132+148) \mathrm{mm}$. Trinomials are used on account of $C . g$. etiennei Schmidt (1919) of Banana, Belgian Congo.

\section{SNAKES}

TYPHLOPS MANN1, new species

Type.-U.S.N.M. No. 109634, from Harbel, Republic of Liberia, March 10-July 17, 1940.

Diagnosis.-Agrees with T. p. punctatus (including its Liberian synonyms of liberiensis Hallowell, nigrolineatus Hallowell, and intermedia Jan) in possessing 26 midbody scalerows. It differs from both $T$. p. punctatus and T. leucostictus in its broad and trilobate snout, lateral nostrils, absence of an ocular, and in its midbody diameter being included in its total length 40 times (instead of 24-36 times in punctatus, 45 in leucostictus). In addition, it differs from leucostictus in possessing 26 (instead of 22) midbody scalerows, a preocular as wide as a nasal, incompletely divided nasal, and-though probably of little significance-completely hidden eyes.

Description.-Snout prominent, trilobate as seen from above, rounded, without obtuse horizontal edge; rostral half the width of the head; nasal swollen, semidivided, the suture extending from the second labial to the nostril, which is lateral; preocular present, as broad as the nasal, much broader than either of the small scales which might be termed an ocular, the lower in contact with the third labial; eyes hidden; only 3 upper labials. Midbody scalerows 26. Diameter of body included 40 times in total length, tail broader than long, ending in an obtuse spine.

Coloration.-About to slough. Above, silvery gray, base of each scale with a transverse brown spot. Below, yellowish gray, with a few fine black flecks.

Measurements. - Total length $343(338+5) \mathrm{mm}$. ; diameter at midbody $8.5 \mathrm{~mm}$.

\section{NATRIX ANOSCOPUS ANOSCOPUS (Cope)}

1861. Tropidonotus anoscopus Cope, Proc. Acad. Nat. Sci. Philadelphia, 1861, p. 299 ["Cuba" (error, probably Liberia)].

1863. Tropidonotus ferox GüNther, Ann. Mag. Nat. Hist., ser. 3, vol. 12, p. 355, pl. 6, fig. F (Fernando Po). 
2 우 우 (U.S.N.M. Nos. 109297-8), Gibi

3 수 ô, 2 우 우 (U.S.N.M. Nos 109585-9), Bendaja

2 ô $\hat{o}, 1$ ㅇ (U.S.N.M. Nos. 109636-8), Harbel

3 ô ô, 1 ㅇ (M.C.Z. Nos. 22505-8), Paiata (G. M. Allen)

Midbody scalerows 23-25; ventrals 138-146; anal divided; subcaudals $65-88$; internasals 2 , rarely single; preoculars 1 , rarely 2 ; postoculars 2 , rarely 1,3 , or 4 ; suboculars $2-4$; temporals $1+2$ or $1+3$; upper labials 9 , rarely 8 or 10 ; lower labials $9-12$. Males may be distinguished readily by the presence of papillalike rugosities on the sublinguals. Largest of (M.C.Z. No. 22505) measures $626(470+$ 156) mm.; largest 우 (M.C.Z. No. 22506) measures $629(473+156)$ $\mathrm{mm}$.

Coloration: Above, blackish or grayish, uniform or with a series of transverse crossbars which may be interrupted dorsally, or obsolescent as a dorsal bar and vertical lateral stripes. Below, white or gray, uniform or more usually with the base of each ventral shield black, rarely (U.S.N.M. No. 109636) with a longitudinal series of black spots.

The stomach of one snake held a toad (Bufo regularis maculatus) and remains of a frog (Rana sp.), that of another a fish (Hemichromis fasciatus). One Bendaja reptile was heavily infested with anisakine nematodes.

The name ferox, by which this water snake has been known until now, must be referred to the synonymy of anoscopus. ${ }^{1}$ Angel (1933, p. 71), after examination of the types of Helicops gendrii Boulenger, referred them to the synonymy of ferox, for he found they bore a sutural scar on the posterior portion of their single internasal. This is exactly the position in two of the present series (U.S.N.M. Nos. 109297, 109586), which have only single internasals. However, Boulenger (1893, p. 241) confused two forms under the name of ferox in his Catalogue. Both of these forms, while normally possessing a pair of internasals, may at times have them fused into a single shield; they can be separated structurally and geographically as follows:

Midbody scale rows 21-25, normally 23; ventrals 138-148 (23 exam-

ples) ; range: Liberia east to Cameroons and Fernando Po-_--- a. anoscopus Midbody scale rows 23-27, normally 25 ; ventrals 146-159 (10 exam-

ples); range: Sierra Leone and French Guinea

a. gendrii

The possibility of retaining ferox as an insular third subspecies with 21 scalerows is rendered impossible by the recording of a snake with 21 rows from Atakpame, Togo, on the mainland.

\footnotetext{
${ }^{1}$ Dr. E. R. Dunn informs me that he reached the same conclusion, after examination of Cope's type.
} 


\title{
NEUSTEROPHIS VARIEGATUS (Peters)
}

1861. Mizodon variegatus Peters, Monatsb. Akad. Wiss. Berlin, 1861, p. 358 (Pel, Gold Coast).

\author{
ô (U.S.N.M. No. 109058), Gibi \\ 우 (U.S.N.M. No. 109307), Bromley \\ ô 우 (U.S.N.M. Nos. 109583-4), Bendaja
}

Midbody scale rows 15; ventrals 124-131; anal divided; subcaudals 75-78; labials 8 , the fourth and fifth entering the orbit; preoculars 1-2. Larger of measures $279(186+93) \mathrm{mm}$; larger of measures 237 from snout to anus, tail truncate.

Bogert (1940, p. 33) advances sound reasons for separation of the smooth-scaled African "Natrix" under Günther's (1858) name of Neusterophis. I take this opportunity of correcting the misidentification of three Paiata, Liberia, snakes reported as Natrix fuliginoides by Barbour and Loveridge (1930, p. 772), and my (1936, p. 21) mistaken action of synonymizing variegatus with fuliginoides on account of their occurrence together at Bitye, Ja River, French Cameroons. The two species are very closely related, practically identical in markings, yet cannot be regarded as races of one species for their ranges are largely coextensive, though variegatus extends farther westward to Liberia and French Guinea. This means that fuliginoides should be deleted from the Liberian list.

\section{BOAEDON LINEATUS VIRGATUS (Hallowell)}

1854. Coelopeltis virgata Hallowell, Proc. Acad. Nat. Sci. Philadelphia, 1854, p. 98 (Liberia).

\section{ô (U.S.N.M. No. 109592), Bendaja}

Midbody scale rows 23 ; ventrals 223 ; anal entire; subcaudals 50 ; labials 8 , the fourth and fifth entering the orbit; preoculars 2 ; postoculars 2 ; temporals $1+2(\mathrm{R})$ and $1+1(\mathrm{~L})$.

Trinomials are used because this extreme western form differs from the nominate species only in the reduced number of midbody scale rows, which, however, is almost constant for Liberia, becoming rarer as one proceeds eastward and unknown east of the Belgian Congo. The region of overlap is very extensive.

BOAEDON LINEATUS LINEATUS Duméril and Bibron

1854. Boaedon lineatus DumérI and Bibron, Erpétologie générale, vol. 7, p. 363 (Gold Coast).

ô (U.S.N.M. No. 109673), Mombo 
Midbody scale rows 27 ; ventrals 197 ; anal entire; subcaudals 63 ; labials 8 , the fourth and fifth entering the orbit; preoculars 2 ; postoculars 2 ; temporals $1+1$.

This house snake so closely resembles the foregoing in color pattern and squamation that there can be no doubt of their close relationship. It constitutes, however, the first recorded occurrence of lineatus in Liberia.

BOAEDON OLIVACEUS (Duméril)

1856. Holurophis olivaceus A. DUмérIL, Rev. Mag. Zool., ser. 2, vol. 8, p. 466 (Gaboon).

ô (U.S.N.M. No. 109590), Bendaja

ô (U.S.N.M. No. 109639), Harbel

Midbody scale rows 25-27; ventrals 208-218; anal entire; subcaudals 39-40, single; labials 8 , the fourth and fifth entering the orbit. Larger ô measures $99(67+32) \mathrm{mm}$.

\section{HAPSIDOPHRYS LINEATA Fischer}

1856. Hapsidophrys lineatus Fischer, Abh. Nat. Ver. Hamburg, vol. 3, p. 111, pl. 2, fig. 5 (Elmine, Gold Coast).

\section{ô (U.S.N.M. No. 109594), Bendaja}

Midbody scale rows 15 ; ventrals 165 ; anal entire; subcaudals ? (tail truncate); upper labials 8 , the fourth and fifth entering the orbit; preocular 1 ; postoculars 2.

\section{RHAMNOPHIS AETHIOPISSA AETHIOPISSA Günther}

1862. Rhamnophis aethiopissa GÜNTHER, Ann. Mag. Nat. Hist., ser. 3, vol. 9, p. 129, pl. 10 (West Africa).

$$
\text { ô (U.S.N.M. No. 109593), Harbel }
$$

Midbody scale rows 16 (for certain); ventrals 165; anal divided; subcaudals $114^{+}$; upper labials 8 , fourth and fifth entering the orbit; preocular 1 ; postoculars 2 , the lower in contact with three upper labials. Total length $1185^{+}\left(805+380^{+}\right)$mm., tail tip truncate.

\section{GRAYIA SMYTHII (Leach)}

1818. Coluber Smythii Leach, in Tuckey, Narrative of an expedition to explore the river Zaire, App., p. 409 (Embomma, i. e. Boma, Belgian Congo).

1854. Coronella triangularis Halloweld, Proc. Acad. Nat. Sci. Philadelphia, 1854, p. 100 (Liberia).

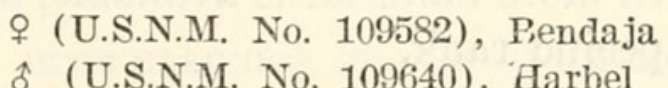

$406739-41-2$ 
Midbody scale rows 17; ventrals 152-161; anal divided; subcaudals 91-99; labials $7-8$, fourth or fifth entering the orbit; temporals $2+3$, the lower anterior longer than its distance from the loreal. Larger, the + , measures only $312(228+84) \mathrm{mm}$.

\section{BOIGA BLANDINGII (Hallowell)}

1844. Dipsas Blandingii Hallowell, Proc. Acad. Nat. Sci. Philadelphia, 1844, p. 170 (Liberia).

1856. Dipsas valida Fischer, Abh. Nat. Ver. Hamburg, vol. 3, p. 87, pl. 3, fig. 4 (Edina, Grand Bassa County, Liberia).

1856. Dipsas globiceps FISCHER, ibid., p. 89, pl. 3, fig. 6 (Edina, Grand Bassa County, Liberia).

\section{ô (U.S.N.M. No. 109306), Bromley}

Midbody scale rows 21; ventrals 264; anal entire; subcaudals 135 ; labials 8 , the third, fourth, and fifth entering the orbit. Total length $1,415(1,085+330) \mathrm{mm}$.

\section{CROTAPHOPELTIS DUCHESNII GUINEENSIS (Chabanaud)}

1920. Leptodira guineensis Chabanaud, Bull. Com. Etudes Hist. Sci. Afrique Occ. Française, 1920, p. 491 (Dieke, Nzerekore region, French Guinea).

\section{우 (U.S.N.M. No. 109645), Harbel}

Midbody scale rows 17 ; ventrals 223; anal entire; subcaudals 111 ; labials 8 , third, fourth, and fifth entering the orbit; loreal sharply distinct, not entering orbit. Total length $733(547+186) \mathrm{mm}$. In its oviducts (March 10-July 17) are 4 eggs, each measuring about 27 by $8 \mathrm{~mm}$.

This species is the genotype of Dipsoglyphophis Barbour and Amaral, 1927, and I should prefer to recognize this name for the group of chunky-headed, attenuate, long-tailed, arboreal snakes (as distinct from the moderate, short-tailed, terrestrial species like $C . h$. hotamboeia) rather than force them into the genus Dipsadoboa (which differs in possessing large vertebrals and single subcaudals) as has been advocated by Bogert (1940, p. 65). Admittedly they occupy an intermediate position between $C$. $h$. hotamboeia and $D$. unicolor, but in head shape $C$. shrevei conforms to hotamboeia rather than to its long-tailed relatives. Nor can I agree with the synonymizing of guineensis with duchesnii Boulenger, from which it differs in several particulars, so that I should have preferred to let it remain as a full species until more material is available, but I compromise in reviving it to subspecific rank. 


\section{MIODON ACANTHIAS (Reinhardt)}

1860. Urobelus acanthias ReinHardt, Vidensk. Medd. Kjøbenhavn, 1860, p. 229, pl. 3 (Guinea).

우 (U.S.N.M. No. 109057), Gibi

Midbody scale rows 15 ; ventrals 212 ; anal entire; subcaudals 17 ; labials 7, the third and fourth entering the orbit. Total length 533 $(505+28) \mathrm{mm}$. In its oviducts (April 10-16) are about 4 eggs, each measuring circa 22 by $7 \mathrm{~mm}$.

\section{APARALLACTUS MODESTUS (Günther)}

1859. Elapops modestus GÜNTHER, Ann. Mag. Nat. Hist., ser. 3, vol. 4, p. 161, pl. 4, fig. C (West Africa).

1860. Periaspis plumbeatra Cope, Proc. Acad. Nat. Sci. Philadelphia, 1860, p. 242 (Liberia).

ㅇ (U.S.N.M. No. 109635), Harbel

Midbody scale rows 15 ; ventrals 154 ; anal entire; subcaudals 36 ; labials 7 , the third and fourth entering the orbit. Total length $465(407+58) \mathrm{mm}$.

\section{DENDROASPIS VIRIDIS (Hallowell)}

1844. Leptophis viridis Hallowelt, Proc. Acad. Nat. Sci. Philadelphia, 1844, p. 172 (Liberia).

1852. Dinophis Hammondii Hallowet, Proc. Acad. Nat. Sci. Philadelphia, 1852, p. 203 (Liberia).

\section{ô (U.S.N.M. No. 109675), Harbel}

Midbody scale rows 13; ventrals 220; anal divided; subcaudals 114 ; labials 8 , the fourth entering the orbit; upper temporal separated from its fellow by three scales. Total length 2,040 $(1,520+520) \mathrm{mm}$.

\section{CAUSUS RHOMBEATUS (Lichtenstein)}

1823. Sepedon rhombeatus Lichtenstein, Verzeichniss der Doubletten des zoologischen Museums . . . zu Berlin, p. 106 (no locality).

1842. Distichurus Maculatus Hallowell, Journ. Acad. Nat. Sci. Philadelphia, vol. 8, p. 337, pl. 19 (Liberia).

ô (U.S.N.M. No. 109591), Bendaja

4 우 (U.S.N.M. Nos. 109641-4), Harbel

Midbody scale rows 19 ; ventrals 128-141; anal entire; subcaudals $17-20$; labials 6 ; suboculars $1-2$. Total length of ô, $497(452+45)$ $\mathrm{mm}$; of largest $\&, 400(365+35) \mathrm{mm}$.

\section{BITIS GABONICA (Duméril and Bibron)}

1854. Echidna Gabonica Dumérir and BiBron, Erpétologie générale, vol. 7, p. 1428, pl. 80b (Gaboon). 
Midbody scale rows 36 ; ventrals 128-130; anal entire; subcaudals 26-28; labials 14 . Both specimens are young.

\section{BITIS NASICORNIS (Shaw)}

1802. Coluber Nasicornis SHAw, Nat. Misc., vol. 3, pl. 94 (interior of Africa) (from the master of a Guinea vessel).

4 ô $\hat{o}, 4$ 우 (U.S.N.M. Nos. 109018, 109676-82), Gibi

ô (U.S.N.M. No. 109308), Bromley

Midbody scale rows 30-38; ventrals 121-129; anal entire; subcaudals 15-26; labials 14-17. Largest î (U.S.N.M. No. 109678) measures $651(570+81)$ mm.; largest 우 (U.S.N.M. No. 109680) measures $955(870+85) \mathrm{mm}$.

\section{FROGS AND TOADS}

\section{XENOPUS TROPICALIS (Gray)}

1864. Silurana tropicalis GRAY, Ann. Mag. Nat. Hist., ser. 3, vol. 14, p. 316 (Lagos, Nigeria).

3 (U.S.N.M. Nos. 109571-3), Bendaja

These frogs have the vestigial lower eyelid and, though less well defined on account of their dry condition, snout and chin beset by pustules characterizing the species as redefined by Parker (1936a, p. 157).

\section{BUFO REgULARIS MACULATUS Hallowell}

1850. Bufo cinereus Hallowell (not Schneider), Proc. Acad. Nat. Sci. Philadelphia, 1850, p. 169 (Liberia).

1854. Bufo maculatus Hallowerl, Proc. Acad. Nat. Sci. Philadelphia, 1854, p. 101 (new name for cinereus, preoccupied).

5 우 우 (U.S.N.M. Nos. 109286-90), Bellyella

1 yng. (U.S.N.M. No. 109305), Bromley

6 yng. (U.S.N.M. Nos. 109554-6, 109666-8), Bendaja

$8 \hat{o} \hat{o}, 1$ 우 (U.S.N.M. Nos. 109622-30), Harbel

1 yng. (U.S.N.M. No. 11314), Reputa

The series maintains the small size of this western form, the very largest ô of (U.S.N.M. No. 109623, etc.) measuring $53 \mathrm{~mm}$., the largest gravid of (U.S.N.M. No. 109286) measuring $67 \mathrm{~mm}$., the youngest toad (U.S.N.M. No. 109556) $15 \mathrm{~mm}$. One of these toads was recovered from the stomach of a water snake (Natrix a. anoscopus).

\section{BUfo CAMERUNENSIS CAMERUNENSIS Parker}

1936. Bufo camerunensis camerunensis PARKer, Proc. Zool. Soc. London, 1936, p. 153 (Oban, Calabar, Nigeria). 
This somewhat dried individual has been compared with a paratype of camerunensis, a species long confused with latifrons Boulenger. First recorded from Liberia by Parker (1936c, p. 97). Length $76 \mathrm{~mm}$.

HYLAMBATES COCHRANAE, new species

Cotypes.-U.S.N.M. Nos. 109569-70, being an adult ô and gravid $q$ from Bendaja, Republic of Liberia, collected by William M. Mann, May 14-27, 1940.

Diagnosis.-Color pattern somewhat resembling that of Kassina senegalensis from which it differs in the possession of well-developed digital disks. Intermediate in position between $H$. cassinoides Boulenger of McCarthy Island, Gambia (with topotypes of which they have been compared), and $H$. leonardi Boulenger of Fernando Po (with Liberian and Congo examples of which they have been compared). It differs from cassinoides in having rather smaller, rounded (instead of subtriangular) disks, broader habit, larger size, and in the thighs and concealed surfaces of tibia and foot exhibiting contrasted black marblings on a white (? red in life) ground. It differs from leonardi in possessing smaller disks; shorter hind limb, which reaches axilla instead of eye; smaller size; and pure white (instead of black) breast and belly, etc.

One wonders if the frogs from French Guinea, referred to Cassina weali of southeast Africa (!) by Chabanaud (1921, p. 460), might not in reality represent this undescribed tree frog.

Description.-Vomerine teeth in two oblique groups situated somewhat posteriorly between the choanae (poorly developed in the of cotype). Head broader than long; snout rounded, shorter than the diameter of the eye, interorbital space broader than an upper eyelid; tympanum rather more than half the diameter of the eye; fingers long, free, with small rounded disks which are half the size of the tympanum; toes half-webbed, their disks smaller than those of the fingers; inner metatarsal tubercle small, rounded, feebly prominent, tibiotarsal articulation of the adpressed hind limb reaches only to the axilla. Skin smooth (or rugosely warty due to immersion in strong alcohol) above; granular on belly and under the thighs. Length of of $36 \mathrm{~mm}$; l length of i $\mathrm{mm}$.

Color in alcohol.-Above, blackish, everywhere with numerous large, oval, light-edged dark spots (as in maculatus); groin, thighs, posterior side of tibia, and upper part of foot, marbled with white ( ? red in life). Below, throat of of black, that of $q$ white with dusky freckles around its labial border; breast and belly of both sexes white with brown vermiculations along the flanks; limbs white (? red) marbled with black; soles chiefly brown mottled with white. 


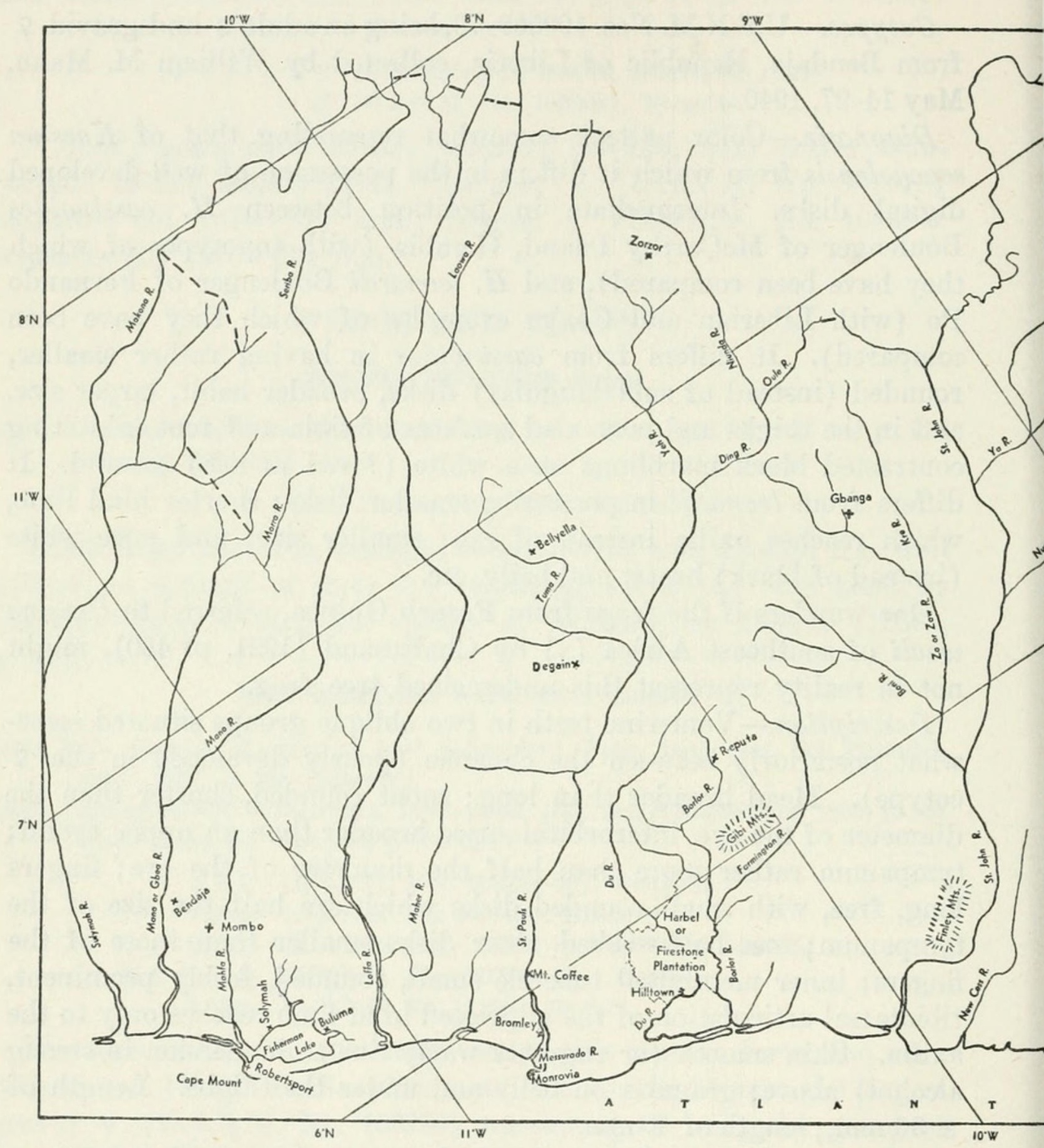

Figure 34.- Liberia. This map was modified by Dr. Leonard P. Schultz from a map of I made to the Geographical Institute of Harv 


\section{HYLAMBATES LEONARDI Boulenger}

1906. Hylambates leonardi Boulenger, Ann. Mus. Stor. Nat. Genova, ser. 3, vol. 2, p. 167, pl. 2, fig. 3 (Punta Frailes, Fernando Po, and N'Djole, French Congo).

\section{ô ô (U.S.N.M. Nos. 109567-8), Bendaja}

In view of this record involving a westward extension of the range of nearly a thousand miles, one might have supposed that they would represent a western race for they differ in several details from the description. Their vomerine teeth are between (not behind the level of) the choanae, though situated somewhat posteriorly; the head is distinctly (not slightly) broader than long; the snout is two-thirds (not equal to) the diameter of the eye; the interorbital space is broader than (not as broad as) an upper eyelid; the tympanum is two-thirds (not two-fifths) the diameter of the eye.

In all these respects, however, they agree with a series (M.C.Z. Nos. 21681-8) of females and young from Djamba, Belgian Congo (det. de Witte), and all with the striking color pattern as figured by Boulenger. There is considerable variation in the amount of white (? red, ? yellow) in the groin and elsewhere. These males exhibit the black vocal sacs flanking the central gular disk which is common to males of their allies of the genus Kassina. Boulenger gave $54 \mathrm{~mm}$. as the length, probably of his cotype $q$ and not of the $\hat{o}$ for the Bendaja ô ô measure $45-47 \mathrm{~mm}$.

\section{LEPTOPELIS VIRIDIS (Günther)}

1868. Hylambates viridis GüntHeR, Proc. Zool. Soc. London, 1868, p. 487 (West Africa).

1929. Leptopelis liberiensis AHL, Sitz. Ges. Naturf. Freunde Berlin, 1929, p. 194 (Liberia).

$2 \hat{o} \hat{o}, 4$ 우 우 (U.S.N.M. Nos. 109530, 109557-61), Bendaja

ô 우 (U.S.N.M. Nos. 109620-1), Harbel

Parker (1936c, p. 95) has cleared up the confusion that has long centered about West African frogs of this group and referred hyloides Boulenger, nanus Ahl, and togoensis Ahl to the synonymy. To these I would now add liberiensis Ahl, described as having a very faint rudiment of web between the fingers but in all other respects agreeing with viridis, which most authors agree to consider as having "fingers free." Males are distinguishable by their dark throats. Length of $\hat{\delta}$ o $30-34$ mm., of ㅇ ㅇ 36-46 mm.

\section{LEPTOPELIS BEQUAERTI, new species}

Correction.-In 1930, Barbour and Loveridge referred certain Liberian frogs to tessmanni Nieden (of Makomo, Spanish Guinea). In 
the absence of topotypic material of Nieden's frog, the Mount Coffee (p. 785) specimens may still be considered to represent tessmanni, but the frogs from Gbanga and Du River (p. 782) that I thought to be young tessmanni must be considered specifically distinct on account of the less developed webbing on both hand and foot. I take pleasure in naming the new species after its collector, Dr. J. Bequaert, who has done so much to advance our knowledge of African zoology in many fields.

Type-M.C.Z. No. 12000, a female from Gbanga, Republic of Liberia, collected by Joseph Bequaert, September 1926.

Paratypes.-Young o (M.C.Z. No. 12001), Gbanga, Liberia (J. Bequaert); $\hat{o}$ and juv. (M.C.Z. Nos. 12002-3), Plantation No. 3, Du River, Liberia (G. M. Allen) ; 우 (U.S.N.M. No. 109051), Gibi, Liberia (W. M. Mann).

Diagnosis.-Digits with a mere rudiment of web; toes with a single joint free of web on the first, second, and third, two joints free on the fourth, a single or only half a joint free on the fifth.

In contrast the Mount Coffee frog (M.C.Z. No. 15939) has only the first finger with a rudiment of web, the second has one joint free, the third two joints, the fourth one and a half joints; of its toes only the first has a single joint free, the second, third and fifth are webbed to the disks on at least one side, the fourth has one and a half (right) to 2 (left) joints free of web. It is a $\hat{o}$ of larger size, viz, $50 \mathrm{~mm}$.

Description.-Vomerine teeth in two small groups between the choanae. Head as broad (or slightly broader than) long; snout roundish, half to two-thirds the diameter of the eye; interorbital space slightly broader than (or as broad as) an upper eyelid; tympanum two-thirds the diameter of the eye; fingers rather long with a mere rudiment of web, their disks as large as the tympanum; toes twothirds webbed, one joint free of web on the first, second, and third toes, two joints free on fourth, half (or one) joint free on fifth, the disks a little smaller than those on the fingers; inner metatarsal tubercle large, oval, strongly compressed; the tibiotarsal articulation of the adpressed hind limb reaches the nostril (or eye). Skin of dorsum shagreened and with small scattered warts; on the throat, belly, and under the thighs, granular; males with a callous pad on the breast in the region of the axilla.

Coloration.-Above, pale brown, a dark, triangular, interorbital marking, its apex directed posteriorly and often confluent with a more or less distinct hourglass pattern on the back; a dark line from the eye passes over the tympanum to the base of the forearm (and may be continued on the flank as a series of dashes); flanks marbled with brown; forearm, thighs, and to some extent the foot, crossbarred with dark brown; from disk of outer finger to elbow, from disk of outer toe 
to heel, and above anus a narrow white line. Below, creamy white sparsely mottled with brown (or uniform); limbs brownish merging into purplish brown on palms and soles.

Measurements.-Length from snout to anus of type $\$, 28 \mathrm{~mm}$.; of paratype $q$ o from Gbanga and Gibi, 29 and $33 \mathrm{~mm}$., respectively; of paratype $\hat{o}, 29 \mathrm{~mm}$; of a juvenile, with rudiment of tail still visible, $15 \mathrm{~mm}$.

\section{MEGALIXALUS FULVOVITTATUS (Cope)}

1860. Hyperolius fulvovittatus Cope, Proc. Acad. Nat. Sci. Philadelphia, 1860, p. 517 (Liberia).

1876. Hyperolius vittiger Peters, Monatsb. Akad. Wiss. Berlin, 1876, p. 122 (Liberia).

17 ô $\hat{o}, 5$ 우 우 (U.S.N.M. Nos. 109534-53, 109664-5), Bendaja

2 우 우 (U.S.N.M. No. 109618-9), Harbel

우 (U.S.N.M. No. 109672), Reputa

ô (U.S.N.M. No. 11318), Cape Mount

All possess the characteristic chocolate-brown dorsal stripes. Length of $\hat{o}$ ô, 23-27 mm., average $24 \mathrm{~mm}$.; length of $q$ ㅇ, 24 $27 \mathrm{~mm}$., average $26 \mathrm{~mm}$., being somewhat less than that of the enormous series from Ganta, Liberia, reported on elsewhere (Loveridge, 1938, p. 66).

\section{MEGALIXALUS PLATYCEPS (Boulenger)}

1900. Rappia platyceps Boulenger, Proc. Zool. Soc. London, 1900, p. 444, pl. 27, fig. 4 (Benito River, French Congo).

ô (U.S.N.M. No. 109533), Bendaja

ô ô (U.S.N.M. Nos. 109616-7), Harbel

A broad vertebral band or hourglass pattern, dorsal spinosities, and vertical pupil present in all. Length of $\hat{o} \hat{o}, 26-29 \mathrm{~mm}$. See remarks in Loveridge (1938, p. 66).

\section{HYPEROLIUS CONCOLOR (Hallowell)}

1844. Ixalus concolor Halloweld, Proc. Acad. Nat. Sci. Philadelphia, 1844, p. 60 (Liberia).

$\begin{aligned} 3 \text { 우 } & \text { (U.S.N.M. Nos. 109531-2, 109655), Bendaja } \\ & \text { ㅇ․ (U.S.N.M. No. 109669), Reputa } \\ & \text { 우 (U.S.N.M. No. 110447), Harbel }\end{aligned}$

Fourth and first toe with one phalange free of web, third scarcely (riggenbachi) or fully (concolor) webbed, second and fifth fully webbed to disks. Three subadult frogs (U.S.N.M. Nos. 109531-2, 109655) are typically riggenbachi Nieden in their dorsal markings, but Mertens (1938, p. 27) considers this to be the juvenile stage of concolor, stating that a riggenbachi, which he captured in the Cameroons, transformed in his vivarium to a typical, uniform concolor. 
One of the two adult females still retains its dorsal coloring of vivid green merging into yellow on the flanks, upper arm, and thighs. Below, uniform white. The subadults measure $23-28 \mathrm{~mm}$., adult $q$ 우, $38-42 \mathrm{~mm}$. Both the latter are gravid, having been taken between March 10-July 17 and June 21-26, respectively.

HYPEROLIUS PLEUROTAENIUS (Boulenger)

1906. Rappia pleurotaenia Boulenger, Ann. Mag. Nat. Hist., ser. 7, vol. 17, p. 322 (Zima, French Cameroons).

ㅇ (U.S.N.M. No. 109040), Gibi

ㅇ (U.S.N.M. No. 109670), Reputa

Fourth toe with one phalange free of web, remaining toes webbed to their disks; tibiotarsal articulation of the adpressed hind limb reaches posterior border of eye. Coloration precisely like that shown on colored plate in Barbour and Loveridge (1930, pl. 465, fig. 4). Length of + \& , 29-37 mm.

\section{HYPEROLIUS PICTURATUS Peters}

1875. Hyperolius picturatus Peters, Monatsb. Akad. Wiss. Berlin, 1875, p. 206, pl. 2, fig. 2 (Boutry, Ashanti, Gold Coast).

3 우 우 (U.S.N.M. Nos. 109309, 109653, 109659), Bendaja

2 우 우 (U.S.N.M. Nos. 109609, 110448), Harbel

Fourth and fifth toe with one phalange free of web, second, third, and fifth webbed almost, or entirely, to their disks; tibiotarsal articulation of the adpressed hind limb reaches to between eye and nostril. Above, pale gray to chocolate-brown, uniform, or with a few black flecks; upper lip and flank with characteristic dark, or black, speckling, marbling or vermiculation. Length of o $~ \&, 27-30 \mathrm{~mm}$. All five are gravid, having been taken between May 14-27 and March 10-July 17 , respectively.

\section{HYPEROLIUS OCELLATUS Günther}

1858. Hyperolius ocellatus GüNTHER, Catalogue of the Batrachia Salientia in the collection of the British Museum, p. 88, pl. 7, fig. B (Fernando Po and Angola).

3 ô ô, 166 우 우 (U.S.N.M. Nos. 109310-453, 109462, 109518-29, 109654,

ㅇ (U.S.N.M. No. 110437), Bendaja

Fourth toe with one phalange free of web, remaining toes webbed to their disks; tibiotarsal articulation of the adpressed hind limb reaches the eye or nostril. Coloration of the largest and smallest frogs is as follows: Above, pinkish white, minutely speckled with brown dots, a few large brown blotches (formed of a concentration of the smaller dots) on back and limbs; a brown canthal streak from nostril to eye. Below, white. Two 23-mm. frogs in the Harbel series are not typical but are so fresh as to have retained certain fugitive 
colors. Above, pale greenish yellow minutely speckled with brown on back and limbs; a brown canthal streak is overlaid by a blood-red band, which continues on from eye to groin as an undulating line; hands and feet blood red. Below, transparently white. Length of ㅇ \& , 22-26 mm. The largest is gravid, having been taken at Harbel between March 10 and July 17.

\section{HYPEROLIUS FUSCIVENTRIS Peters}

1876. Hyperolius fusciventris PeTers, Monatsb. Akad. Wiss. Berlin, 1876, p. 122 (Liberia).

우 (U.S.N.M. No. 109041), Gibi

3 ô ô, 166 우 우 (U.S.N.M. Nos. 109310-453, 109462, 109518-29, 109654, 109656-8, 110438-46), Bendaja

24 우 우 (U.S.N.M. Nos. 109595-607, 109646-9, 110451-7),

\section{Harbel}

우 (U.S.N.M. No. 109671), Reputa

Fourth and first toe with one phalange free of web, second and third with one-half or one phalange free, fifth webbed to disk; tibiotarsal articulation of the adpressed hind limb reaches the eye or nostril. Coloration, 우 오: Above, blue-gray (green in life), an irregular, undulating, often broken, black line extends from below commissure of mouth over forearm to groin, sometimes continued over thigh to meet its fellow below anus, similar wavy lines present on anterior and posterior aspect of fore limb, tibia, and foot. Below, pale to lead gray, almost black. A few individuals (U.S.N.M. Nos. 109380, 109394, 109404, 109518-23, 109605) lack the lateral line in varying degrees and may be classed as underpigmented and overpigmented as they vary from very pale gray to dark plumbeous above, and all are paler below, the pallid specimens being actually white. One might suppose that they were young concolor but for the fact that most of them are gravid and usually carry, in the shape of scattered specks, some traces of the whereabouts of the typical markings. The $\hat{o}$ o differ slightly. Above, pale gray; a black canthal stripe present or absent; a few conspicuous black spots on flanks; a light dorsolateral line (as in ademetzi, which see) from posterior border of eye towards groin, just discernible in one frog. Below, white. Length of $\hat{\delta} \hat{\delta}$, 21-22 mm.; of 50 우 ㅇ, 22-28 mm., average $25 \mathrm{~mm}$.

\section{HYPEROLIUS ? ADEMETZI Ahl}

1931. Hyperolius ademetzi AHL, Mitt. Zool. Mus. Berlin, vol. 17, p. 37 (Bamenda, British Cameroons).

50 ô $\hat{o}, 18$ 우 우 (U.S.N.M. Nos. 109454-61, 109463-517, 109660-3, 11315), Bendaja

9 ô ô (U.S.N.M. Nos. 109610-5, 109650-1, 110458), Harbel

Fourth and first toe with one phalange free of web, second and 
third with one-half a phalange free, or webbed to disk like fifth; tibiotarsal articulation of the adpressed hind limb reaches the eye or nostril. A light dorsolateral line almost always present. Every specimen has a more or less conspicuous, dark-edged, silvery, nasolateral stripe; the density of pigmentation on the dorsum varies considerably, reaching its maximum in U. S. N. M. No. 109469, in which even the gular disk and throat are stippled, though as colorless as the belly in most of the series. Seven males (U.S.N.M. Nos. 109454, 109456, 109459, 109461, 109481, 109610, 109612), though indistinguishable as to color and pattern, may be males of some other dimorphic and slightly larger species, possibly picturatus, for they measure 24-29 mm., average $26 \mathrm{~mm}$. Length of 50 ô ô, 19-23 mm., average $22 \mathrm{~mm}$., length of 18 presumed + o (assumed to be so as without gular disks, but certainly young, and possibly including some young males among them) $16-23 \mathrm{~mm}$., average $19 \mathrm{~mm}$.

These frogs are conspecific with the 143 of $\hat{o}$ and 5 o $\circ$ previously reported upon, which I $(1938$, p. 69$)$ treated in the same way for reasons stated at that time. In view of the preponderance of male ademetzi in both collections, paralleled by the predominance of female fusciventris, one might be tempted to assume that we were dealing with a single species exhibiting sexual dichromatism. A careful examination of the earlier material, however, lends no weight to such an assumption, and one must conclude that the ademetzi males are assembling to summon their females at a time when the fusciventris females are ovulating. The majority of fusciventris females collected by Dr. Mann are distended with ova, but none of the ademetzi females appears gravid.

\section{HYPEROLIUS ? FESTIVUS Barbour and Loveridge}

1927. Hyperolius festivus BARBour and Loveridge, Proc. New England Zoöl. Club, vol. 10, p. 17 (Firestone Plantation No. 3, Du River, Republic of Liberia).

\section{? ô (U.S.N.M. No. 109052), Gibi}

Above, brown, but lips and flanks white, instead of dark; the absence of the dark hourglass pattern on the dorsum is of no importance, as it is absent in a + paratype of festivus. This rather dried specimen has no gular disk but a baggy singing pouch. Length, $26 \mathrm{~mm}$. It seems probable that festivus, as well as baumanni Ahl, of which we have a Togo cotype, will probably have to be synonymized with acutirostris Peters, of Cameroons, of which we have no typical material.

\section{SYNOPSIS OF THE SPECIES OF RANA IN LIBERIA}

In connection with this work I came across a specimen (M.C.Z. No. 24461) of Rana longirostris Peters that constitutes the first Liberian 
record of this Gold Coast (type locality, Keta) species of which aequiplicata Werner, of the Cameroons and Congo, is a synonym according to Nieden, who made direct comparison of the types.

The specimen comes from the Firestone Plantation No. 3, on the $\mathrm{Du}$ River, Liberia, where it occurs together with $R$. maccarthyensis (M.C.Z. Nos. 24462-3), R. o. gribinguiensis (M.C.Z. Nos. 24458-60), $R$. o. oxyrhynchus (M.C.Z. Nos. 24455-7), and R. m. mascareniensis (M.C.Z. Nos. 11927-31), the latter having been erroneously recorded under the name bibronii in 1930.

In view of the remarkable similarity of all these frogs and the consequent difficulty of distinguishing them, it seemed advisable to draw up the following key after a careful examination of Dr. Mann's material together with that in the Museum of Comparative Zoölogy.

1. A conspicuous transverse fold connects posterior edges of upper eyelids; toes webbed to tips; habit robust

No transverse fold across crown of head; habit more or less slender

2. Vomerine teeth in two oblique rows, anteriorly touching inner posterior edge of choanae, posteriorly converging; snout acuminate, as long as, or almost as long as, orbital diameter; tympanum sharply distinct, large, its diameter almost that of orbit; tips of toes not dilated, at most thickened

occipitalis

Vomerine teeth (absent in young) in two round groups between, but posterior to an imaginary line connecting hind edges of, choanae; snout rounded, once and a half as long as orbital diameter; tympanum indistinct, small, its diameter about a third that of orbit; tips of toes dilated into distinct, though small, disks

3. Vomerine teeth in two oblique rows between, though not in contact with, choanae; tips of fingers and toes dilated into distinct disks.

Fourth toe with only 1 phalange free of web (or which may be continued up it as a narrow seam to disk), remaining toes webbed to base of their disks; tibiotarsal articulation of adpressed hind limb reaches eye or just beyond end of snout; vocal sacs of $\hat{\delta}$ internal, but a glandular swelling present at base of forearm in $\hat{\delta} \hat{\delta}$

Vomerine teeth in two rows projecting inward from anterior
edges of choanae; tips of fingers and toes simple, not dilated-a. albolabris inner and an outer metatarsal tubercle, latter connected by a series of minor tubercles with first subarticular tubercle of fourth toe.

Fourth toe with 2 (rarely 3 ) phalanges free of web, first toe with $1 \frac{1}{2}$ (rarely 1 or 2 ), second with 1 (rarely $1 \frac{1 / 2}{2}$ ), third with 1 (rarely 2), fifth with $1 / 2$ (rarely 1 or $1 \frac{1}{2}$ ) phalanges free of web; tibiotarsal articulation of adpressed hind limb reaches nostril or well beyond end of snout; vocal sac of $\hat{o}$ external, its aperture extending posteriorly toward lower insertion of forearm maccarthyensis

An inner metatarsal tubercle only, no minor tubercles on basal phalange of fourth toe 
5. Fourth toe with only 1 phalange free of web (though sometimes second represented only by a narrow seam in o. gribinguiensis), fifth webbed to tip

Fourth toe with 2 or more phalanges free of web

6. First, second, and third toes with $1 / 2$ a phalange free of web; tibiotarsal articulation of adpressed hind limb reaches end of snout or far beyond; adult 우 우 $50-58 \mathrm{~mm}$ longirostris

First, second, and third toes webbed to tips ; tibiotarsal articulation of adpressed hind limb reaches well beyond or far beyond end of snout; inhabits rain forest; size larger, adult 우 우 58-74 $\mathrm{mm}$

o. gribinguiensis

7. Fifth toe webbed to tip; vocal sac of ô external, its aperture extending posteriorly toward lower insertion of forearm.

Fourth toe with 2 phalanges free of web; first, second, and third toes with 1 phalange free of web; tibiotarsal articulation of adpressed hind limb reaches nostril or just beyond end of snout; adult ㅇ ㅇ 53-55 mm_-_-_-_.-. o. oxyrhynchus

Fifth toe with 1 or more phalanges free of web. 8

8. Fourth toe with $2 \frac{1}{2}$ phalanges free of web, first, second, and third toes with 1 (or rather more than 1) phalange free, fifth with only 1 free; tibiotarsal articulation of adpressed hind limb reaches nostril or just beyond end of snout; vocal sac of $\hat{o}$ external, its aperture extending posteriorly toward upper insertion of forearm m. mascareniensis

Fourth toe with 3 phalanges free of web, first, third, and fifth with 2 , second with $1 \frac{1}{2}$ phalanges free of web; tibiotarsal articulation of adpressed hind limb reaches well beyond or far beyond end of snout; vocal sac of $\hat{o}$ external, its aperture extending posteriorly toward lower insertion of forearm bibronii

\section{RANA OCCIPITALIS Günther}

1858. Rana occipitalis GÜNTHeR, Catalogue of the Batrachia Salientia in the collection of the British Museum, p. 130, pl. 11 (Gambia) (restricted).

$$
\begin{aligned}
& \text { ô, } 2 \text { 우 우 (U.S.N.M. Nos. 109299-301), Bromley } \\
& 3 \text { oิ } \hat{o}, 2 \text { 우 우 (U.S.N.M. Nos. 109574-8), Bendaja }
\end{aligned}
$$

Characters as in foregoing synopsis. Length of $\hat{o}$ ô, $80-93 \mathrm{~mm}$.; of 우 ㅇ, , 82-94 mm.

\section{RANA CRASSIPES ALLENI (Barbour and Loveridge)}

1927. Pseudoxenopus alleni Barbour and Loveridge, Proc. New England Zoöl. Club, vol. 10, p. 14 (Firestone Plantation No. 3, Du River, Liberia).

$$
\text { Yng. and ô (U.S.N.M. Nos. 109050, 11313), Gibi }
$$

Characters as in foregoing synopsis. Length of $\hat{o}, 65 \mathrm{~mm}$. Parker (1931, p. 493) has accidentally reversed the character of snout length in relation to that of occipitalis. It seems best to regard alleni as the western race of crassipes as suggested by Parker. 
RANA ALBOLABRIS ALBOLABRIS Hallowell

1856. Rana albolabris HALLowell, Proc. Acad. Nat. Sci. Philadelphia, 1856, p. 153 (West Africa).

$$
\begin{array}{r}
2 \text { ô } \hat{o}, 2 \text { 우 } \\
\text { 우 (U.S.N.M. Nos. 109053-6), Gibi } \\
\text { (U.N.M. No. 109304), Bromley }
\end{array}
$$

Characters as in foregoing synopsis. Length of $\hat{o} \hat{o}, 42-45 \mathrm{~mm}$; of ㅇ ㅇ, 38-51 mm. As R. a. acutirostris Parker (1936b, p. 141) is preoccupied by $R$. acutirostris Fatio (1872), I take pleasure in renaming the former, of which we have a paratype, parkeriana, after its describer.

\section{RANA MACCARTHYENSIS Andersson}

1937. Rana maccarthyensis ANDERsson, Arkiv Zool., vol. 29A, No. 16, p. 9, figs. 3-4 (Maccarthy Island, Gambia).

\section{오 (U.S.N.M. No. 109038), Gibi}

\section{3 ô ô, 3 ㅇ 우 (U.S.N.M. Nos. 109265-70), Bellyella}

Characters as in foregoing synopsis. It is a $q$ and $3 \hat{o} \hat{o}$ (U.S.N.M. Nos. 109267-70) that have such long hind limbs as to necessitate expanding the description in this respect. Length of $\hat{o} \hat{o}, 42-43 \mathrm{~mm}$; of 우 오, 51-64 mm.

\section{RANA OXYRHYNCHUS OXYRHYNCHUS Smith}

1849. Rana oxyrhynchus A. SмIтH, Illustrations of the zoology of South Africa, Rept., pl. 77, figs. 2, 2a-c (Kaffirland and the region of Port Natal, South Africa).

ô (U. S. N. M. No. 109039), Gibi

ㅇ (U.S.N.M. No. 109302), Bromley

juv. (U.S.N.M. No. 109652), Bendaja

Characters as in foregoing synopsis, except that the $23-\mathrm{mm}$. juvenile has rather more extensive webbing and should perhaps be referred to $R$. o. gribinguiensis Angel, which occurs in the rain-forest areas of Liberia. Length of $\widehat{o}, 41 \mathrm{~mm}$.; of $q, 53 \mathrm{~mm}$.

\section{RANA MASCARENIENSIS MASCARENIENSIS Duméril and Bibron}

1841. Rana mascareniensis DumérIL and BIBRon, Erpétologie générale, vol. 8, p. 350 (Madagascar; Mauritius; Seychelles).

$$
\begin{aligned}
& 4 \text { ô } \hat{o}, 1 \text { ㅇ (U.S.N.M. Nos. 109033-7), Gibi } \\
& 9 \text { ô } \hat{o}, 4 \text { 우 우 (U.S.N.M. Nos. 109271-83), Bellyella } \\
& \text { 우 (U.S.N.M. No. 109303), Bromley } \\
& \text { ô (U.S.N.M. No. 109579), Bendaja }
\end{aligned}
$$

Characters as in foregoing synopsis. Length of adult $\hat{o} \hat{o}, 46-55$ $\mathrm{mm}$; of adult o 우, 54-64 mm. While possessing the short hind limbs of the typical form, the Bellyella frogs reach the large size of the rainforest race venusta Werner. 


\section{ARTHROLEPTIS POECILONOTUS Peters}

1863. Arthroleptis poecilonotus Peters, Monatsb. Akad. Wiss. Berlin, 1863, p. 446 (Boutry, Ashanti, Gold Coast).

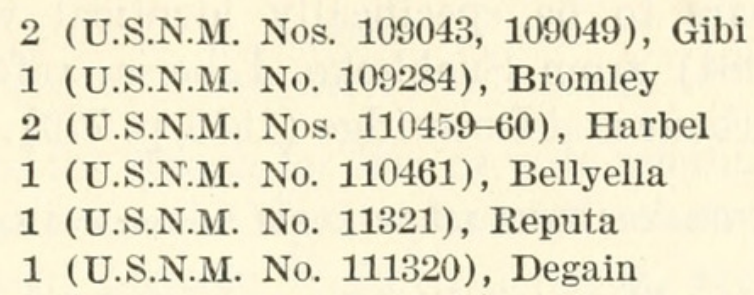

A single metatarsal tubercle; tibiotarsal articulation of the adpressed hind limb reaches to between eye and nostril in all. Length of adults, $25-27 \mathrm{~mm}$.; of juveniles, $12-16 \mathrm{~mm}$.

\section{ARTHROLEPTIS CALCARATUS (Peters)}

1863. Hemimantis calcaratus Peters, Monatsb. Akad. Wiss. Berlin, 1863, p. 452 (Boutry, Ashanti, Gold Coast).

$$
\text { Juv. (U.S.N.M. No. 111322), Gibi }
$$

Two metatarsal and a tarsal tubercle; tibiotarsal articulation of the adpressed hind limb reaches nostril; upper eyelid with a small wart in lieu of the elongate tubercle characteristic of the adult, with whose coloring it is in fairly close agreement though the spotting on throat and breast is even more pronounced. Length of juv., $12 \mathrm{~mm}$.

\section{ARTHROLEPTIS WERNERI Nieden}

1910. Arthroleptis werneri NiEDEN, Arch. Naturg., vol. 76, pt. 1, p. 242 (Banjo district and Bamenda, British Cameroons).

\section{우 (U.S.N.M. No. 111319), Gibi}

Two metatarsal and a tarsal tubercle, of which the inner is equidistant from the outer as from the tarsal tubercle; tibiotarsal articulation of the adpressed hind limb reaches the posterior border of the eye; upper eyelid warty; snout slightly longer than the orbit. Throat and lower flanks finely vermiculate. Length of $\%, 20 \mathrm{~mm}$. Gravid when taken April 10-16.

As stated by Parker (1936c, p. 93) the identification of Liberian frogs with werneri should be regarded as tentative until direct comparison has been made with Cameroons material.

\section{PHRYNOBATRACHUS NATALENSIS (Smith)}

1849. Stenorhynchus natalensis A. SMITH, Illustrations of the zoology of South Africa, Rept., App., p. 24 (Natal, South Africa).

\section{우 (U.S.N.M. No. 109042), Gibi}

Three phalanges of the fourth toe free of web, first and second with 1 , third and fifth with 2 phalanges free; tibiotarsal articulation 
of the adpressed hind limb reaches the eye. Length of $\%, 36 \mathrm{~mm}$. This frog, which constitutes the first record of the species from Liberia, has been compared carefully with specimens from the Natal border; it appears to be specifically identical with the juvenile (M.C.Z. No. 11984) from Suahkoko, Liberia, referred to francisci Boulenger by Barbour and Loveridge (1930, p. 779).

\section{PHRYNOBATRACHUS LIBERIENSIS Barbour and Loveridge}

1927. Phrynobatrachus liberiensis Barbour and Loveridge, Proc. New England Zoöl. Club, vol. 10, p. 14 (Gbanga, Liberia).

Hgr. (U.S.N.M. No. 111316), Degain

Three phalanges of the fourth toe free of web, first and second toe narrowly webbed to the disk on one side only, third and fifth with 2 phalanges free; tibiotarsal articulation of the adpressed hind limb reaches just beyond end of snout. Length of hgr., $24 \mathrm{~mm}$.

\section{PHRYNOBATRACHUS PLICATUS (Günther)}

1858. Hyperolius plicatus GüNTHER, Catalogue of the Batrachia Salientia in the collection of the British Museum, p. 88, pl. 7, fig. C (Coast of Guinea).

\section{Juv. (U.S.N.M. No. 111317), Mombo}

Two phalanges of the fourth toe free of web, third phalange with a narrow margin only; remaining toes webbed to their disks though second and third toes only narrowly on one side; tibiotarsal articulation of the adpressed hind limb reaches well beyond tip of snout; characteristic dorsal glandular folds present. Length of juv., $18 \mathrm{~mm}$.

\section{PHRYNOBAtrachus OgOEnsis BRONGersmai Parker}

1936. Phrynobatrachus brongersmai PARker, Zool. Meded., vol. 19, p. 90 (Grand Cape Mount, Liberia).

2 (U.S.N.M. Nos. 109048, 110462), Gibi

우 (U.S.N.M. No. 109562), Bendaja

ô (U.S.N.M. No. 110463), Reputa

Two phalanges of the fourth toe free of web, first and second with half or 1 , third and fifth with 1 phalange free; tibiotarsal articulation of the adpressed hind limb reached the eye (in gravid $q$ ) or beyond end of snout (in three ? ô $\hat{o}$ ). Length of $\hat{o} 16-17 \mathrm{~mm}$.;

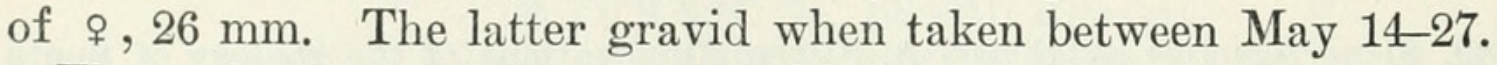

The of has a vocal sac, though this is one of the three characters used by Parker to distinguish the Liberian frog from the slightly smaller ogoensis Boulenger, to which Barbour and Loveridge (1930, p. 780) referred certain Liberian frogs. The latter are certainly conspecific with the present material. 


\section{PHRYNOBATRACHUS LATIFRONS Ahl}

1924. Phrynobatrachus latifrons AHL, Zool. Anz., vol. 60, p. 272 (Dodo, French Cameroons).

3 (U.S.N.M. Nos. 109045-7), Gibi

4 (U.S.N.M. Nos. 109563-6), Bendaja

Two phalanges of the fourth toe free of web, remaining toes webbed to their disks at least on one side, but less fully than in alleni for the web is deeply incised between digits; tibiotarsal articulation of the adpressed hind limb reaches the eye or nostril. Lengths $22-25 \mathrm{~mm}$. Females from both localities gravid when taken between April 10-16 and May 14-27 respectively.

\section{PHRYNOBATRACHUS ALLENI Parker}

1936. Phrynobatrachus alleni PARKer, Zool. Meded., vol. 19, p. 91 (Firestone Plantation No. 3, Du River, Liberia).

1 (U.S.N.M. No. 109044), Gibi

Two phalanges of the fourth toe free of web, remaining toes fully webbed to their disks, at least on one side; tibiotarsal articulation of the adpressed hind limb reaches end of snout. Length, $28 \mathrm{~mm}$. 


\section{LITERATURE CITED}

Angel, Fernand.

1933. Les serpents de l'Afrique Occidentale Française, 246 pp., 83 figs. Paris.

Barbour, Thomas, and Loveridge, Arthur.

1930. Reptiles and amphibians from Liberia. In Strong, R.: Report of the Harvard-African Expedition upon the African Republic of Liberia and the Belgian Congo, vol. 2, pp. 769-786, 2 pls. Cambridge, Mass.

Bogert, Charles Mitchill.

1940. Herpetological results of the Vernay Angola Expedition. Bull. Amer. Mus. Nat. Hist., vol. 77, art. 1, pp. 1-107, 18 figs., 1 pl.

Boulenger, George Albert.

1893. Catalogue of snakes in the British Museum (Natural History), vol. 1, xiii +448 pp., 26 figs., 28 pls. London.

1920. Monograph of the Lacertidae, vol. $1, x+352$ pp. London.

Chabanaud, Paul.

1921. Contribution à l'étude de la faune herpétologique de l'Afrique occidentale. Deuxieme note. Bull. Com. Etudes Hist. Sci. Afrique Occidentale Française, pp. $445-472$, map, 4 pls.

LOVERIDGe, ARTHUR.

1936. African reptiles and amphibians in Field Museum of Natural History. Field Mus. Nat. Hist. Zool. Ser., vol. 22, pp. 1-111.

1938. On a collection of reptiles and amphibians from Liberia. Proc. New England Zoöl. Club, vol. 17, pp. 49-74.

Mertens, RoBert.

1938. Herpetologische Ergebnisse einer Reise nach Kamerun. Abh. Senck. Naturf. Ges., No. 442, pp. 1-52, 10 pls.

Parker, Hampton Wildman.

1931. Some new and rare frogs from West Africa. Ann. Mag. Nat. Hist., ser. 10 , vol. 7 , pp. $492-498$.

1936a. The amphibians of the Mamfe Division, Cameroons: (1) Zoogeography and systematics. Proc. Zool. Soc. London, 1936, pp. 135-163, 8 figs., $1 \mathrm{pl}$.

1936b. Dr. Karl Jordan's expedition to Southwest Africa and Angola. Herpetological collections. Nov. Zool., vol. 40, pp. 115-146, 2 figs.

1936c. Amphibians from Liberia and the Gold Coast. Zool. Meded., vol. 19, pp. 87-102.

140 


\section{$2 \mathrm{BHL}$ Biodiversity Heritage Library}

Loveridge, Arthur. 1941. "Report on the Smithsonian-Firestone Expedition's collection of reptiles and amphibians from Liberia." Proceedings of the United States National Museum 91, 113-140.

https://doi.org/10.5479/si.00963801.91-3128.113.

View This Item Online: https://www.biodiversitylibrary.org/item/32533

DOI: https://doi.org/10.5479/si.00963801.91-3128.113

Permalink: https://www.biodiversitylibrary.org/partpdf/22879

\section{Holding Institution}

Smithsonian Libraries

\section{Sponsored by}

Smithsonian

\section{Copyright \& Reuse}

Copyright Status: NOT_IN_COPYRIGHT

Rights: https://www.biodiversitylibrary.org/permissions/

This document was created from content at the Biodiversity Heritage Library, the world's largest open access digital library for biodiversity literature and archives. Visit BHL at https://www.biodiversitylibrary.org. 